\title{
Analysis of Effectiveness of Internal Control System for Use of Village Fund in Villages of Bangunrejo Subdistrict Lampung Central District
}

\begin{abstract}
Muhammad Zulvan Dwi Hatmoko
${ }^{I}$ Nusa Putra University, Sukabumi, Indonesia

Corresponding author.E-mail: mzulvan12@gmail.com

ABSTRACT

This research objects to analyze whether the internal control system of Bangunrejo village is effective in preventing fraud. The respondents in this research consist of village equipment and community representatives whore a totally 4 representatives. Collecting data in this research using interview, observation, and documentation methods. Research results show that the control system works effectively enough. This is because there are still inadequate control components in analyzing the risk of using village funds. The monitoring and evaluation components are not satisfactory in following up the audit results. This research is expected to provide improvement suggestions to Bangunrejo village to improve its internal control system in preventing fraud in the use of village funds.
\end{abstract}

Keywords: Internal Control System, Village Funds.

\section{INTRODUCTION}

Law no. 6 the Year 2014 on the village gives the village freedom to manage and manage its finances. In 2017 each village was budgeted IDR 720 million from APBN. To achieve the ideals of village funds, village governments need to implement an internal control system. The internal control system is within governance aims to create good village governance [1]. In 2016 the Commission received 362 community reports related to data funds. The survey results show that there are 62 cases of corruption tacked by the village government entered the investigation stage, with the estimated state losses reaching IDR 18 billion. The results of initial interviews conducted with the Secretary of Bangunrejo Sub-district also showed that the financial statements made by the village government have not been following the rules, and there are still some villages that make fictitious reports. The above information shows that the internal control system of village funds is still fragile.

Government organizations that already have internal control systems tend to be more effective and efficient in running [2]. The role of the internal control system within the government is to prevent fraud and improve transportation and efficiency [3].
The internal control system can run efficiently by protecting public funds and budgets, enforcing laws and regulations, developing accounting systems, fraud prevention, and corruption [4]. Based on the above description, this study wanted to analyze the SPI in the Village Sinar Luas District Bangunrejo Central Lampung Regency. Has the SPIP implementation been effectively implemented?

\section{LITERATURE REVIEW}

\subsection{Internal Control System}

Internal Control System is an Integrated process continously to provide valid proof on the accomplishment of organizational goals through effective and efficient activities, reliability of financial reporting, security state assets and compliance with statutory regulations [4]. All government agencies are required to exercise control in organizing government activities.

The success rate of an internal control system in village funds is measured based on the fulfillment of five elements of control, among others; the creation of a good and effective control environment, the design of a risk assessment system in the use of village funds, 
controlled and directed control activities, the result of good information and communication systems, and the creation of control and monitoring activities creation of control and monitoring activities [6].

\subsection{Effectiveness and Success of Government Internal Control System}

The effectiveness of the internal control system can be seen from the conformity of the results with what is aspired [7]. If what the internal control system desires is not by what has been achieved, then the internal control system is considered ineffective. Running the internal control system requires internal control components that function together, are integrated and have relevant principles that are run effectively and efficiently [8]. In this case, COSO tackles the characteristics of an effective internal control system lies in the process, meaning the consequences and awareness of the importance of the internal control system is the responsibility of the leader and all individuals in the organization. The concept of "tone at the top" where the government's leadership still has a central role in implementing the internal control system [9]. Then effective internal control system can help reduce the risks that can lead to the non-achievement of organizational goals. Four factors influence the success in the implementation of an internal control system in government, among others (1) human resources (HR); (2) commitment; (3) exemplary leadership; (4) availability of infrastructure [10].

\subsection{Village Financial Management}

According to Permendagri No. 113 the Year 2014 on Management of Village Finance, there are five stages in managing village finances among others is (1) planning; (2) implementation; Administration; (4) Reporting; (5) accountability.

\section{RESEARCH METHODS}

This research uses a qualitative approach. Data collection techniques used interview, observation, and documentation. The interviews were divided into the internal control questionnaire (ICQ) and in-depth interviews. Icq interviews were used to measure the effectiveness of the internal control system in sinar luas village by involving two respondents, namely the village head and village secretary. In-depth interviews were used to retrieve information about the internal control system of village funds by involving four respondents, namely the village head, village secretary, village treasurer, and village community representatives (lpmk). Observations are used to verify the results of ICQ interviews. Word is done by plunging directly into the activity process and direct observation of each event also mencara documents as additional evidence in the study.

Data analysis used a method developed by the champion. Here is the formula of conversion of research results.

\section{$\boldsymbol{x}$ \\ $=\frac{\text { Number of Answer "Yes" }}{\text { Number of Questions }} \times 100 \%$}

The sectoral results of the presentation are then used as a basis for concluding, based on the classification as presented in the table below.

Table 1. Results of the presentation

\begin{tabular}{|c|c|}
\hline Score & $\begin{array}{c}\text { Government Internal Control } \\
\text { System }\end{array}$ \\
\hline $0-25 \%$ & Ineffective \\
\hline $25-50 \%$ & Less Effective \\
\hline $50-75 \%$ & Effective Enough \\
\hline $75-100 \%$ & Very Effective \\
\hline
\end{tabular}

Analytical methods for in-depth interviews using techniques developed by Miles and Huberman. Three stages are used to analyze qualitative data: data reduction, display data, and conclusions [11]. Data reduction is the process of summarizing or filtering data obtained from the field so that the data to be presented into detail; the following process is display data can be done by making the table, make a brief description or flowchart goal for data easily understood; the final process of a conclusion is the final stage of presenting verifiable findings.

Validity in qualitative research is different from validity in quantitative analysis. Qualitative validity is an examination of the accuracy of the research results by using specific procedures [12]. Eight validity strategies are often used in quantitative research. This research uses two validity strategies is triangulation and member checking.

\section{RESULTS AND DISCUSSION}

\subsection{Results}

\subsubsection{Control Environment}

The following explains the effectiveness level of each component of the control environment. The average level of environmental effectiveness control of $68 \%$ means quite effective. Enforcement of integrity and ethical values has the lowest percentage of $25 \%$, which is ineffective. Commitment to competency and delegation of authority has the 
highest value with $100 \%$, meaning very effective. Other components such as facilitative leadership and human resource development policies and practices have a discount of $78 \%$ and $71 \%$, which is quite effective. Elements of organizational structure and the embodiment of the role of apparatus have a value of $50 \%$, which means less effective.

\subsubsection{Risk Assessment}

The average level of effectiveness of risk assessment is $44 \%$, which means that risk assessment in running village funds is ineffective. The following explains the effectiveness level of each risk assessment component. Based on the ICQ result, the effectiveness of determining total agency objectives in Sinar Luas Village is $75 \%$, which means that the internal control system is very effective. The value of goal setting effectiveness at the level of activity in Sinar Luas Village is $60 \%$ means that the internal control system is quite effective. The value of risk identification effectiveness in Sinar Luas Village is $20 \%$, meaning that the internal control system is not practical. The value of risk identification effectiveness in Sinar Luas Village is $25 \%$, meaning that the internal control system is ineffective.

\subsubsection{Control Activities}

The average level of activity control effectiveness is $71 \%$, which means that the control activities in running the village funds are pretty practical. The following describes the level of energy of each component of the control activity. Based on the ICQ results, the effectiveness of reviewing the performance of the relevant government agencies in Sinar Luas Village is $0 \%$, meaning that the internal control system is ineffective. The value of human resources development effectiveness in Sinar Luas Village is $100 \%$, which means the internal control system is very effective. The value of information management effectiveness in Sinar Luas Village is $50 \%$, meaning the internal control system is less effective. The value of the efficacy of physical control of assets in the village of Sinar Luas is $63 \%$ means that the internal control system is quite effective. The value of point of implementation and review of indicators and performance measures in the village of Sinar Luas is $100 \%$ means the internal control system is adequate. The value of the effectiveness of functional redaction in Sinar Luas Village is $100 \%$, meaning that the internal control system is adequate. The value of authority effectiveness on transactions and important events in Sinar Luas Village is $100 \%$, meaning that the internal control system is adequate. The significance of restrictions on access to resources and recording in Sinar Luas Village is $100 \%$, meaning that the internal control system is adequate. The value of good documentation effectiveness on the internal control system and actual transactions and events in Sinar Luas Village is $100 \%$, meaning that the internal control system is adequate.

\subsubsection{Information and Communication}

The average level of information and communication effectiveness of $83 \%$, which means that risk assessment in running the village funds is efficient. Here is an explanation of the effectiveness level of each information and communication compiler. Based on ICQ results, the value of information effectiveness in Sinar Luas Village is $100 \%$, meaning that the internal control system is very effective. The value of communication effectiveness in Sinar Luas Village is $100 \%$ means that the internal control system is very effective. The value of the point of the forms and facilities in the village of Sinar Luas is $50 \%$ means that the internal control system is inadequate.

\subsubsection{Monitoring and Evaluation}

The average monitoring and evaluation effectiveness level is $71 \%$, which means that risk assessment in running village funds is reasonably practical. The following explains the effectiveness of each monitoring and evaluation component. Based on the ICQ results, the point of monitoring and sustainability in Sinar Luas Village is $100 \%$, meaning that the internal control system is very effective. The value of separate evaluation effectiveness in Desa Sinar Luas is $57 \%$ means that the internal control system is quite effective. The value of independent evaluation effectiveness in Desa Sinar Luas is $57 \%$ means that the internal control system is quite effective.

\subsection{Discussion of Research Findings}

The results mentioned above show that the information and communication components have an efficient value with a percentage of $83 \%$. Control environment, control activities, and monitoring and evaluation have "effectiveness" effectiveness rating levels. Percentage of each level of effectiveness assessment, i.e., control environment equal to $68 \%$, control activity equal to $71 \%$, and monitoring and evaluation equal to $71 \%$. However, the risk assessment component has a "less effective" effectiveness score with a percentage of $44 \%$. During the research results, there are some findings in the application of SPI the use of village funds either directly related to the SPI component or to collecting the research evidence.

\subsubsection{Control Environment}

Based on the above findings, four components of the control environment have a value of effectiveness below $75 \%$ : the enforcement of integrity and ethical 
values, organizational structure, policies and practices of human resources development, and the realization of effective internal government oversight apparatus. Discussion of the control room components: (1) Enforcement of integrity and ethical values, Sinar Luas Village, has no regulation on integrity and ethics, discipline in work, and sanctions for infringing employees. (2) organizational structure Outer rays do not yet have organizational structures that describe the duties and functions of each structure; (3) human resources development policies and practices, Sinar Luas Village, does not provide orientation or introduction before working on village funds; (4) the realization of the role of effective internal government oversight apparatus, Sinar Luas Village does not get the output from the Inspectorate in writing, making it difficult for the village government to evaluate and improve performance.

\subsubsection{Risk Assessment}

Based on the above findings, there are four components of risk assessment that have a value of effectiveness below $75 \%$, i.e., goal setting at the activity level, risk identification, and analysis Discussion of risk assessment components as follows (1) goal setting at the activity level, goal setting at activity level found Sinar Luas Village did not review any existing activities whether still following the agreed medium-term plan (RPJM); (2) risk identification and risk analysis, Desa Sinar Luas does not yet have risk assessment indicators and has not been able to analyze the risks that may arise from the use of village funds.

\subsubsection{Control Activities}

Based on the above findings, there are four components of control activities that have a value of effectiveness below $75 \%$, that is, review of the performance of relevant government agencies, information management, and physical control of assets. Discussion of the components of the above control activities as follows (1) reviews of the performance of the relevant government agencies, government agencies such as districts or Inspektorat do not review the achievements of activities or programs conducted by Desa Sinar Luas; (2) information management Village Sinar Luas, has not made a financial report by the rules of PP. 71 the Year 2010 on Government Accounting Standards which at the time of making financial statements still use manual bookkeeping system while the government has set up an accounting system in making village financial reports (SIKUDES); (3) physical control of assets, currently Sinar Luas Village has no internal mechanism for periodically calculating fixed assets, the non-calculation of fixed assets makes the village government has no books or records of fixed assets.

\subsubsection{Information and Communication}

Based on the findings above, one component of information and communication has value effectiveness below 75\%: form and means. The discussion of the above information and communication components is as follows (1) the structure and the standards, the absence of a public complaint tool to convey the aspirations and problems that occurred in the village is one of the problems found in the information and communication component.

\subsubsection{Monitoring and Evaluation}

Based on the findings above, one monitoring and evaluation component has an effectiveness value below $75 \%$, separate evaluation, and completion of an audit. Discussion of the above information and communication components as follows (1) separate evaluation, evaluation findings conducted by districts or Inspectorate are not socialized to the parties in need so the village government can not socialize it because there is no written evaluation result given by subdistrict and Inspectorate; (2) audit completion, Desa Sinar Luas never did a review and evaluate audit findings because the Inspectorate of Central Lampung District did not give a result of a report of examination (LHP) to Sinar Luas Village for three consecutive years.

\subsubsection{Community Participation}

The village of Sinar Luas always involves the community in deciding on the use of village funds by making village musyawarah. The village authorities have implemented an essential point of village funding: participation and transparency. Involving communities in any activities related to village funds will strengthen oversight and control in using village funds. The community will oversee every training or program created and run by the village.

\subsubsection{Understanding Employees about SPI}

The understanding of the officials in the village government in Sinar Luas Village is still very little related to the internal control system. Most of the resource persons are field workers who do not understand the rules of SPI. So that informants are less informative in providing information.

\section{CONCLUSION}

\subsection{Conclusion}

Based on the analysis of the collected data, it was concluded that the village of Sinar Luas Subdistrict Bangunrejo had run SPI using the village funds in the Village Sinar Luas Bangunrejo District. Running SPI 
in using village funds is quite effective with $65 \%$. This is because there are still some SPI components that have not been implemented, as follows.

1) Control Environment

a) The absence of written rules relating to upholding integrity and ethical values, discipline work, and sanctions to employees.

b) The organizational structure has not clearly explained the tasks, functions, and reporting.

c) Desa Sinar Luas does not have an orientation program for new employees who will work.

d) The absence of the result of supervision report given by Inspectorate to SinarLuas Village.

2) Risk Assessment

a) Sinar Luas Village does not review any existing activities, whether it is following the agreed medium-term plan (RPJM). The village head also does not conduct periodic reviews of the performance of the exercises. There is no document on the accuracy and achievement of each activity that can later become the evaluation material.

b) Desa Sinar Luas does not yet have an indicator of risk assessment and has not been able to analyze the risks that may arise from the use of village funds.

3) Control Activities

a) Government agencies such as Kecamatan or Inspectorate do not conduct reviews on the achievement of activities or programs executed by Sinar LuasVillage.

b) The management of information in preparing the financial statements is not by the rules of PP. 71 the Year 2010 on Government AccountingStandards, which at the time of making financial statements, still use a manual bookkeeping system while the government has prepared an accounting system to make village financial reports (SIKUDES). The village of SinarLuas also has not made information about budget realization in public places.

c) Sinar Luas Village has no internal mechanism for periodically calculating fixed assets. Sinar Luas Village also does not have a plan related to recovering assets in case of loss or damage caused by the disaster or disaster.
4) Information and Communication

a) The absence of public complaints means conveying the aspirations and problems that occur in the village.

5) Monitoring and evaluation

a) Sinar Luas Village did not socialize the evaluation findings conducted by the subdistrict or Inspectorate to the parties in need.

b) The Inspectorate of Central Lampung District did not give a result of the inspection report (LHP) to Sinar Luas Village for three consecutive years.

\subsection{Suggestions}

Several suggestions can be given related to this research.

1) Control environment

a) Sinar Luas Village is suggested to make rules related to integrity and ethical values. The village government can involve the community in making the rule. The government discusses discipline and sanctions in work.

b) Sinar Luas Village is suggested to create an organizational chart and be displayed in the village hall to provide information to the kegawai about the duties and functions, the reporting path in working or giving information to the community-related information transparency to the community.

c) Sinar Luas Village is suggested to make the program related to new employee orientation. Sinar Luas village can do basic training related to positions and responsibilities to maximize potential new employees and minimize the risk of errors in the work.

d) The government's internal oversight apparatus must provide evaluation results to the village government. The village government should also ask for the examination results from the authorities concerned.

2) Risk assessment

The village government can utilize the early consultation of the year by involving the community to review each activity in the APBDesa whether it is still in line with the objectives of the RPJM.

a) The village head is advised to review the purpose of regular village fund use activities to find out the performance of the village government in carrying out 
activities. Desa Sinar Luas suggests reviewing each activity whether it is still by the objectives in the RPJM. The Village Head can create a timeliness table, the accuracy of the budget, and the output of activities undertaken by the village government.

b) Establish indicators of risk assessment accompanied by village counselors. Subsequently, village counselors in Desa Sinar Luas should provide periodic training on risk analyses.

3) Control activities

a) Government agencies such as Kecamatan or Inspectorate are advised to review and oversee the achievement of programs or activities made by the village government. Sub-district or Inspectorate can regularly and regularly schedule programs such as inspection, monev, or sidag.

b) The government should begin to socialize the importance of usingSIKUDES in making village financial reports and make strict sanctions against villages that have not yet used SIKUDES in preparing their financial statements. The village government must also commit to using SIKUDES to make village financial reports immediately. The village government is also advised to publicize the budget realization by creating billboards or banners containing the budget realities and displayed in public places that the public can see and read.

c) Sinar Luas Village is suggested to make village asset inventory book. The village government can calculate and record all existing assets in the village government. The village government is also advised to create scheduled activities to count all purchases and match them with records or inventory books.

4) Information and communication

a) The village government should facilitate the community by providing a complaint box as a means and information in applying the use of village funds.

5) Monitoring and evaluation

a) Sinar Luas Village is suggested to socialize the revaluation result conducted by Inspector or Sub-District to the officer responsible for leading the program and activities. The purpose of the matter is so that the responsible employee can know the errors and performance in work. The village government can disseminate the findings to village meetings.

b) The village government should request the report results relating to the Inspectorate's audit results. The goal is that the village government has reference materials to make improvements.

\section{REFERENCES}

[1] T. Taufik, "The effect of internal control system implementation in realizing good governance and its impact on fraud prevention," Int. J. Sci. Technol. Res., vol. 8, no. 9, pp. 2159-2165, 2019.

[2] Y. D. Kricy and M. Simbel, "Pengaruh Sistem Pengendalian Intern Pemerintah (SPIP) terhadap perencanaan dan pelaksanaan anggaran dana desa di Kecamatan Mentaya Hulu, Kabupaten ...," J. Environ. Manag., 2021, [Online]. Available: https://ejournal.upr.ac.id/index.php/jem/article/view/2 943.

[3] E. Y. Kasim, "Effect of government accountants competency and implementation of internal control to the quality of government financial reporting.," Int. J. Business, Econ. Law, vol. 8, no. 1, pp. 97-105, 2015.

[4] L. Ionescu, "The Role of Accounting and Internal Control in Reducing Bureaucracy in the Public Sector," J. Econ. Dev. Environ. People, vol. 5, no. 4, pp. 46-53, 2016.

[5] K. C. Lelly and N. N. Afiah, "Does quality of financial statement affected by the internal control system and internal audit?," Int. J. Econ. Financ. Issues, vol. 7, no. 2, pp. 568573, 2017, [Online]. Available: https://dergipark.org.tr/en/download/articlefile/365935\%0Ahttp:www.econjournals.com.

[6] M. A. A. Aziz, H. A. Rahman, M. M. Alam, and J. Said, "Enhancement of the Accountability of Public Sectors through Integrity System, Internal Control System and Leadership Practices: A Review Study," Procedia Econ. Financ., vol. 28, no. April, pp. 163-169, 2015, DOI: 10.1016/s22125671(15)01096-5.

[7] M. W. Yusran, B. Yogaswara, and ..., "Perancangan Pengukuran Sistem Manajemen Kinerja Pt Bhakti Unggul Teknovasi Menggunakan Metode Balanced Scorecard," eProceedings ..., vol. 6, no. 2, pp. 6946-6953, 2019, [Online]. Available: 
https://openlibrarypublications.telkomunivers ity.ac.id/index.php/engineering/article/view/1 0892.

[8] L. F. Spira and M. Page, "Risk management: The reinvention of internal control and the changing role of internal audit," Accounting, Audit. Account. J., vol. 16, no. 4, pp. 640-661, 2003, DOI: 10.1108/09513570310492335.

[9] G. A. Rubasundram, "Perceived 'Tone From the Top' During A Fraud Risk Assessment," Procedia Econ. Financ., vol. 28, no. April, pp. 102-106, 2015, DOI: 10.1016/s22125671(15)01087-4.
[10] N. N. Afiah and P. C. Azwari, "The Effect of the Implementation of Government Internal Control System (GICS) on the Quality of Financial Reporting of the Local Government and its Impact on the Principles of Good Governance: A Research in District, City, and Provincial Government in South Sumatera," Procedia - Soc. Behav. Sci., vol. 211, pp. 811818 , 2015 ,

DOI: 10.1016/j.sbspro.2015.11.172.

[11] L. S. Lotto, M. B. Miles, and A. M. Huberman, "Qualitative Data Analysis: A Sourcebook of New Methods," Educ. Eval. Policy Anal., vol. 8, no. 3, p. 329 , 1986, DOI: $10.2307 / 1163741$.

[12] T. C. Guetterman, M. D. Fetters, and J. W. Creswell, "Integrating quantitative and qualitative results in health science mixed methods research through joint displays," Ann. Fam. Med., vol. 13, no. 6, pp. 554-561, 2015, DOI: $10.1370 / \mathrm{afm} .1865$. 